\title{
Precentral gyrus infarct presenting as isolated contralateral peripheral-type facial palsy
}

Benjamin Hebant, MD, Guillaume Costentin, MD, Mélina Slama, MD, and Evelyne Guegan-Massardier, MD Neurology ${ }^{\circledR}$ 2018;91:421-422. doi:10.1212/WNL.0000000000006090

\section{Correspondence}

Dr. Hebant

benjamin.hebant@

gmail.com

Figure 1 Photograph of the patient demonstrates a right peripheral-type facial palsy

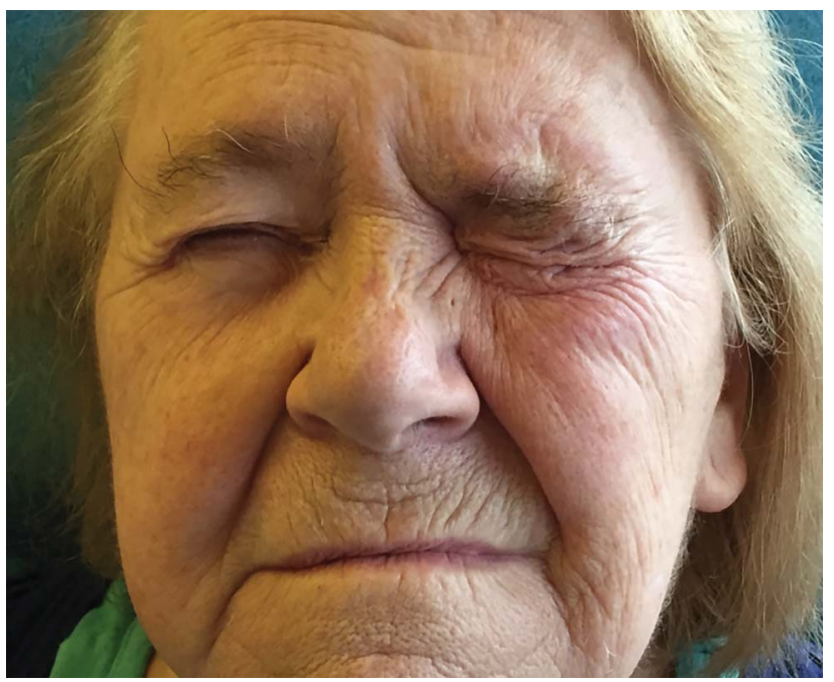

We observed decreased movement of both the upper and lower part of the face with asymmetry of eyelid closure during maximal effort.

A 78-year-old hypertensive woman was assessed for acute right facial weakness. Examination showed isolated right peripheral-type facial palsy (weakness of upper and lower face) (figure 1). Brain MRI revealed focal restricted diffusion in the left precentral gyrus (figure 2). Weakness of

Figure 2 Brain MRI

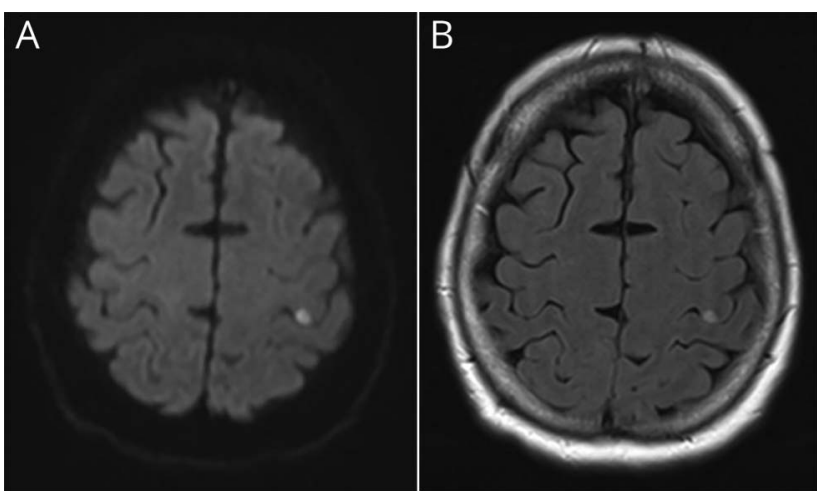

(A) Axial diffusion-weighted imaging sequence demonstrates a small area of restricted diffusion in the left precentral gyrus. (B) Axial fluid-attenuated inversion recovery image shows a hyperintensity signal in the same area. 
upper facial muscles can be seen in central facial paralysis ${ }^{1,2}$ but is not usually isolated. Studies in monkeys suggest that both upper and lower facial nucleus receive bilateral cortical inputs; our case suggests that the upper facial nucleus could receive less cortical input than the lower. ${ }^{3}$ Since the upper face motor representation is in both middle and anterior cerebral arteries territories, ${ }^{4}$ we hypothesize that involvement of critical zones of the Rolandic area can account for upper facial weakness, a crucial diagnostic challenge, the differential being Bell palsy.

\section{Author contributions}

Dr. Hebant: study concept and design. Dr. Costentin: critical revision of the manuscript for important intellectual content. Dr. Slama: critical revision of the manuscript for important intellectual content. Dr. Guegan-Massardier: critical revision of the manuscript for important intellectual content.

\section{Study funding}

No targeted funding reported.

\section{Disclosure}

The authors report no disclosures relevant to the manuscript. Go to Neurology.org/N for full disclosures.

\section{References}

1. Lin J, Chen Y, Wen H, Yang Z, Zeng J. Weakness of eye closure with central facial paralysis after unilateral hemispheric stroke predicts a worse outcome. J Stroke Cerebrovasc Dis 2016;26:834-841.

2. Hägg M, Tibbling L. Four-quadrant facial function in dysphagic patients after stroke and in healthy controls. Neurol Res Int 2014;2014:672685.

3. Jenny AB, Saper CB. Organization of the facial nucleus and corticofacial projection in the monkey: a reconsideration of the upper motor neuron facial palsy. Neurology 1987;37:930-939.

4. Cattaneo L, Saccani E, De Giampaulis P, Crisi G, Pavesi G. Central facial palsy revisited: a clinical-radiological study. Ann Neurol 2010;68: 404-408.

\section{Get 10 AAN Practice Management Webinars for Less than \$19 Each}

The AAN is dedicated to helping neurologists improve their practices and delivery of quality care to their patients. The AAN's Practice Management Webinars provide the valuable insights and tools you need to navigate through the ever-changing health care landscape-and receive year-end CME credits!

Purchase webinars individually for $\$ 99$ each, or subscribe to the complete series of 2018 webinars for only $\$ 189-$ that's less than $\$ 19$ per webinar! See the list of webinars and subscribe at AAN.com/view/pmw18.

\section{Visit the Neurology ${ }^{\circledR}$ Resident \& Fellow Website}

Click on Residents \& Fellows tab at Neurology.org.

Now offering:

- Neurology ${ }^{\circledR}$ Resident \& Fellow Editorial team information

- "Search by subcategory" option

- E-pearl of the Week

- RSS Feeds

- Direct links to Continuum ${ }^{\circledR}$, Career Planning, and AAN Resident \& Fellow pages

- Recently published Resident \& Fellow articles

- Podcast descriptions

f Find Neurology ${ }^{\circledR}$ Residents \& Fellows Section on Facebook: http://tinyurl.com/o8ahsys

Follow Neurology ${ }^{\circledR}$ on Twitter: http://twitter.com/GreenJournal 


\section{Neurology}

Precentral gyrus infarct presenting as isolated contralateral peripheral-type facial palsy Benjamin Hebant, Guillaume Costentin, Mélina Slama, et al. Neurology 2018;91;421-422

DOI 10.1212/WNL.0000000000006090

This information is current as of August 27, 2018

$\begin{array}{ll}\begin{array}{l}\text { Updated Information \& } \\ \text { Services }\end{array} & \begin{array}{l}\text { including high resolution figures, can be found at: } \\ \text { http://n.neurology.org/content/91/9/421.full }\end{array} \\ \text { References } & \text { This article cites } 4 \text { articles, } 1 \text { of which you can access for free at: } \\ \text { http://n.neurology.org/content/91/9/421.full\#ref-list-1 } & \text { This article, along with others on similar topics, appears in the } \\ \text { following collection(s): } & \text { Clinical neurology examination } \\ \text { http://n.neurology.org/cgi/collection/clinical_neurology_examination } \\ \text { Critical care } \\ \text { http://n.neurology.org/cgi/collection/critical_care } \\ \text { Infarction } \\ \text { http://n.neurology.org/cgi/collection/infarction }\end{array}$

Neurology ${ }^{\circledR}$ is the official journal of the American Academy of Neurology. Published continuously since 1951, it is now a weekly with 48 issues per year. Copyright (O 2018 American Academy of Neurology. All rights reserved. Print ISSN: 0028-3878. Online ISSN: 1526-632X.

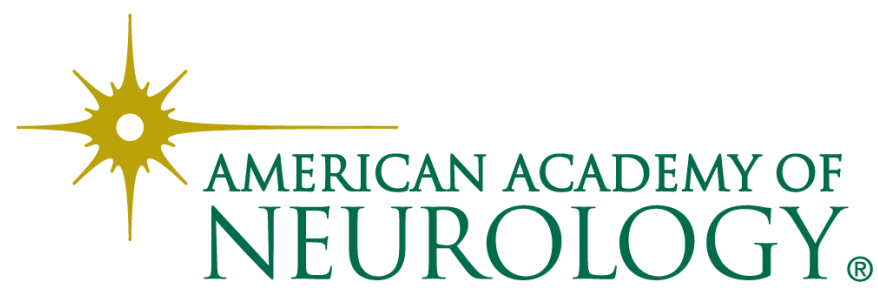

